\title{
GLCCI1 Polymorphism rs37973 and Response to Treatment of Asthma With Inhaled Corticosteroids
}

\author{
Rijavec $M^{1}$, Žavbi $M^{1}$, Lopert $A^{2}$, Fležar $M^{1}$, Korošec $\mathrm{P}^{1}$ \\ 'University Clinic of Respiratory and Allergic Diseases Golnik, Golnik, Slovenia \\ ${ }^{2}$ Outpatient Practice for Pulmonary Diseases and Allergy, Murska Sobota, Slovenia
}

J Investig Allergol Clin Immunol 2018; Vol. 28(3): 165-171

doi: 10.18176/jiaci.0229

\begin{abstract}
Background: The response to asthma treatment is highly variable, and having pharmacogenetic markers that predict response to treatment would bring us one step closer to personalized treatment. Genome-wide association studies have shown that polymorphisms in GLCCI1 could be associated with the response to inhaled corticosteroids (ICSs) in asthma patients.

Materials and methods: We genotyped rs37973 in GLCCI1 in 208 adult asthma patients treated with ICSs. The percentage change in $\mathrm{FEV}_{1}, \%$ predicted was analyzed after short-term treatment ( 3 months) and long-term treatment (at least 3 years). Treatment was defined as successful when $\mathrm{FEV}_{1}$ decreased by $<30 \mathrm{~mL} /$ year.

Results: After 3 months of treatment, FEV 1 \% predicted was higher in patients with the GG genotype than in patients with the AG+AA genotype, and this genotype-dependent difference was only evident in nonsmokers. Similar results were found in nonsmokers and patients with atopy after at least 3 years of treatment, when all patients were analyzed. Even though no differences were observed for success of treatment (good vs poor response) when the whole group of patients was analyzed, genotype-dependent treatment success was highly influenced by smoking and atopy. The GG genotype was overrepresented in nonsmokers and patients with atopy and a good response. Conclusions: rs37973 was associated with response to short- and long-term treatment; however, smoking and atopy had a considerable effect on pharmacogenetic association. Furthermore, in contrast with findings from genome-wide association studies, we found the GG genotype to be associated with better treatment response.
\end{abstract}

Key words: Pharmacogenetics. rs37973. GLCCI1. FEV 1. Smoking. Atopy.

\section{Resumen}

Introducción: La respuesta al tratamiento del asma es muy variable y los marcadores farmacogenéticos que predicen esta respuesta nos sitúan más cerca del tratamiento personalizado. Los estudios de asociación de genoma completo (GWAS) han demostrado que los polimorfismos GLCCI1 podrían estar asociados con la respuesta al tratamiento con corticosteroides inhalados (ICS).

Material y métodos: Se genotipó el polimorfismo de un solo nucleótico (SNP) rs37973 de GLCCI1 en 208 pacientes adultos con asma tratados con ICS. El cambio en el porcentual del FEV 1 predicho se analizó después de un tratamiento a corto plazo ( 3 meses) y después de un tratamiento a largo plazo (al menos 3 años). El éxito del tratamiento se definió como bueno cuando el FEV disminuyó menos de $30 \mathrm{ml} / \mathrm{año}$.

Resultados: Después de 3 meses de tratamiento, el cambio en el porcentual del FEV 1 predicho fue mayor en pacientes con genotipo GG que en pacientes con genotipo $A G+A A$, y esta diferencia asociada al genotipo solo fue evidente en los no fumadores. Se encontraron resultados similares en el análisis de la muestra completa de pacientes después de al menos 3 años de tratamiento, tanto en no fumadores como en pacientes atópicos. A pesar de que no se observaron diferencias en el éxito del tratamiento (buena frente a mala respuesta) al analizar todo el grupo de pacientes, el éxito del tratamiento dependiente del genotipo estuvo muy influenciado por el tabaquismo y la atopia. El genotipo GG estaba sobrerrepresentado tanto en los pacientes no fumadores como en los pacientes con atopia, con buena respuesta al tratamiento.

Conclusiones: El SNP Rs37973 se asoció con una respuesta al tratamiento con corticoides inhalados a corto y largo plazo. Sin embargo, hubo una gran influencia del tabaquismo y la atopia en esta asociación farmacogenética. Además, encontramos que el genotipo GG se asocia con una mejor respuesta al tratamiento, lo que es contrario a los resultados encontrados en otros estudios de tipo GWAS.

Palabras clave: Farmacogenética. Rs37973. GLCCI1. FEV 1 . Tabaquismo. Atopia. 


\section{Introduction}

Asthma is one of the most common chronic diseases worldwide, with an estimated 300 million persons affected [1]. First-line treatment comprises inhaled corticosteroids (ICSs), the only therapy that suppresses airway inflammation and simultaneously inhibits many inflammatory targets [2]. ICSs decrease airway vascularity, abnormal vascular permeability, basement membrane thickness, and airway hyperresponsiveness and increase forced expiratory volume in the first second $\left(\mathrm{FEV}_{1}\right)$ [3]. Despite the efficacy of ICSs, response to treatment is highly variable between patients. Multiple factors - genetic, environmental, and asthma-related - are likely to contribute to the heterogeneous response to corticosteroids. However, since the response is highly reproducible within the same patient, it is assumed that genetic factors contribute significantly to response variability [4,5]. Single-nucleotide polymorphisms (SNPs) are increasingly studied as possible markers for predicting response to treatment [6]. In asthma, the many genes that have been associated with response include $T B X 21, V E G F A$, and CRHR1 [7-9]. A recent genome-wide association study (GWAS) found rs37973 in a promoter region of glucocorticoid-induced transcript 1 (GLCCI1) to be a major candidate associated with response to ICSs in asthma patients, and the results were further replicated in an additional cohort [10]. GLCCI1 encodes a protein with an unknown function but whose expression is induced by glucocorticoids and may be an early marker for glucocorticoid-induced apoptosis. Two previous genetic association studies aimed to replicate the original findings for the polymorphism rs37973, in which the minor $G$ allele was associated with a poorer response to treatment [10]. In the first study, the authors used a 2-SNP model-rs37973 in GLCCI1 combined with rs1876828 in CRHR1-and were able to discriminate between very good and very bad responders [11]. In the second study, which was performed on adult asthmatics [12], the only relevant finding was a trend in the same direction as in the GWAS study [10].

The pharmacogenetic variants in asthma analyzed to date account for only a small portion of genetic variability in the response to asthma treatment. Several factors, such as environmental effects and complex genetic background, predispose to phenotypically heterogenous disease [13] and substantially complicate asthma pharmacogenetics. Litonjua et al [14] found an association between response to treatment and polymorphisms in the $\beta_{2}$-adrenergic receptor only in nonsmoking patients. Furthermore, an association has been reported between treatment response and genotype only in atopic patients with moderate persistent asthma [15]. Indeed, it is well accepted that there are several asthma endotypes $[5,16]$. The response to treatment might vary substantially between different endotypes and should be taken into consideration when performing pharmacogenetic studies and, more importantly, when performing replication studies.

The current study aims to identify the modulating effects of rs37973 in the GLCCI1 gene on response to ICSs in adult patients with asthma (smokers and nonsmokers, atopic and nonatopic) in the short term (3 months) and long term (at least 3 years).

\section{Material and Methods}

\section{Patients}

The study population comprised 208 Slovenian adults with atopic and nonatopic, mild-to-moderate persistent asthma who were seen at a respiratory medicine outpatient

Table 1. Clinical Characteristics and Genotype of the GLCCI1 Polymorphism of Patients With Asthma

\begin{tabular}{|c|c|c|c|c|c|c|}
\hline & All Patients & Atopic Patients & Nonatopic Patients & Smokers & Nonsmokers & $P$ Value \\
\hline Patients, No. (\%) & 208 & $90(43)$ & $118(57)$ & $53(25)$ & $155(75)$ & \\
\hline Mean (SD) age, y & $43(14)$ & $36(13)$ & $49(12)$ & $44(14)$ & $43(15)$ & \\
\hline Male sex, No. (\%) & $70(43)$ & $41(46)$ & $29(24)$ & $25(47)$ & $45(29)$ & \\
\hline \multicolumn{7}{|l|}{ Median (IQR) $\mathrm{FEV}_{1} \%$ predicted } \\
\hline At baseline & $84(18)$ & $88(19)$ & $83(20)$ & $79(17)$ & $87(19)$ & \\
\hline Change after 3 mo of treatment ${ }^{b}$ & $5(9)$ & $5(10)$ & $6(9)$ & $5(7)$ & $5(9)$ & $P<.001$ \\
\hline Change after $>3$ y of treatment $t^{b}$ & $4(9)$ & $4(11)$ & $4(8)$ & $4(10)$ & $4(9)$ & $P<.001$ \\
\hline $\begin{array}{l}\text { Median (IQR) } \mathrm{PD}_{20} \\
\text { at baseline, } \mathrm{mg}^{\mathrm{c}}\end{array}$ & $0.65(1.09)$ & $0.56(1.10)$ & $0.69(1.09)$ & $0.48(0.87)$ & $0.71(1.20)$ & $P<.001$ \\
\hline \multicolumn{7}{|l|}{ Genotype, No. (\%) } \\
\hline AA & $71(34)$ & $29(32)$ & $42(36)$ & $22(42)$ & $49(32)$ & \\
\hline AG & $101(49)$ & $47(52)$ & $54(46)$ & $22(42)$ & $79(51)$ & \\
\hline GG & $36(17)$ & $14(16)$ & $22(19)$ & $9(17)$ & $27(17)$ & \\
\hline
\end{tabular}

aSignificance of changes from baseline for the entire group of 208 patients (Wilcoxon matched-pairs signed rank test).

${ }^{b}$ The change from baseline in the $\mathrm{FEV}_{1}, \%$ predicted after 3 months and after $>3$ years of treatment.

'The change from baseline $\mathrm{PD}_{20}$ in $\mathrm{mg}$ after 3 years of treatment. 
clinic. Clinical parameters and demographic data are listed in Table 1. At the first visit, lung function was assessed and methacholine challenge tests were performed. All patients had a positive result in the methacholine challenge test (decrease in baseline $\mathrm{FEV}_{1}$ of $20 \%$ with a cumulative dose of methacholine $\left[\mathrm{PD}_{20}\right]$ less than $4 \mathrm{mg}$ ), and most had normal or near-normal spirometry testing results. After the diagnosis was established, all patients started treatment with inhaled corticosteroids (alone or in combination with a long-acting $\beta_{2}$-agonist [LABA], depending on the degree of asthma control). Patients attended follow-up visits with spirometry testing after 3 months and after at least 3 years of treatment (mean [SD], 4.6 [1.3] years). The $\mathrm{FEV}_{1}, \%$ predicted value was measured at all 3 time points. After at least 3 years of treatment, the response was defined as good or poor. A poor response was defined as a decrease in $\mathrm{FEV}_{1}$ of more than $30 \mathrm{~mL} /$ year. All spirometry and methacholine challenge testing was performed by the same technician, using the same method (dosimeter) and equipment (Spirojet, Provojet Nebulizer) to avoid bias. Patients were seated and wearing nose clips. Clinical data are reported in detail in our previous study [7]. The present study was conducted in accordance with the amended Declaration of Helsinki and approved by the Slovenian Ethics Committee. All patients gave their written informed consent to participate.

\section{DNA Isolation and SNP Genotyping}

Genomic DNA was extracted from EDTA tubes of whole blood samples using a QIAamp DNA Blood Mini Kit (QIAGEN) according to the manufacturer's instructions. The genotypes of the SNP rs37973 in GLCCI1 were determined using a specially designed SNP assay (Applied Biosystems). The approach followed comprised a forward primer CTCTTTTCACTGCATAACTACAAATGTTAGG, reverse primer CTTCTGGTGATCAGGAGAAATGTCT, and probe TTGTTCA[G/A]TGCAGGTTC labeled with VIC and FAM fluorescent dyes and NFQ quencher. Genotyping was performed using an ABI 7500 Fast Real-Time PCR system with SDS v2.0.5 software (Applied Biosystems).

\section{Statistical analysis}

The Hardy-Weinberg equilibrium was tested using the $\chi^{2}$ test for the goodness-of-fit (1 degree of freedom model). Data distribution was evaluated using the D'Agostino and Pearson test. Parametric statistics (paired and unpaired $t$ test) were used for normally distributed data, and nonparametric statistics (Mann-Whitney, Wilcoxon test, and Kruskal-Wallis test) were used for nonnormally distributed data. Genotypic distribution and allelic frequencies were compared using the Fisher exact test based on contingency tables. Odds ratios with $95 \%$ confidence intervals $(95 \% \mathrm{CI})$ were calculated using the same test. We used the GraphPad PRISM program (version 5.0 for Windows, GraphPad Software). A $P$ value less than .05 was considered statistically significant. We calculated power using R [17]. The proportion of the high-risk genotype (GG) among cases/controls was estimated using a risk allele frequency of 0.41 , a risk trait population prevalence (estimated frequency of good responders to ICS) of 0.8 , and a high-risk genotype relative risk estimation of 1.3 (recessive inheritance model). The evaluation of the proportion of the high-risk genotype among cases/controls using the above parameters was 0.208 and 0.0083 , respectively. The stimulation method was then used to calculate power (1000 stimulated samples with sample sizes concordant with the number of cases/controls for each individual property of the studied group and the type I error of less than .05).

\section{Results}

\section{Response to Treatment and GLCCI1}

Lung function improved in asthma patients treated with ICSs, as average $\mathrm{FEV}_{1}$, \% predicted increased from $84 \%$ before treatment to $90 \%$ after 3 months $(P<.001)$ and $89 \%$ after at least 3 years of treatment $(P<.001)$. However, the change in $\mathrm{FEV}_{1} \%$ predicted ranged from a $28 \%$ decline to a $49 \%$ improvement, with wide variability between patients (Figure 1). Furthermore, according to the criteria defined in Methods, $17 \%$ of patients had a poor response after at least 3 years of treatment with ICSs.

We genotyped for rs37973 in the GLCCI1 gene and found that 71 patients $(34 \%)$ were major AA homozygotes, 101 (49\%) were heterozygotes, and 36 (17\%) were minor GG homozygotes, similar to the CEU population. The genotype distribution of the polymorphism analyzed was in HardyWeinberg equilibrium. There was no genotype-dependent difference in $\mathrm{FEV}_{1}, \%$ predicted before treatment.

\section{Short-term Treatment and GLCCI1}

We analyzed the association between rs37973 in GLCCI1 and change in lung function, defined as change in $\mathrm{FEV}_{1}, \%$ predicted in patients with asthma after short-term treatment with ICSs (3 months). To assess the effect of environment and disease phenotypes on the pharmacogenetics of ICSs in patients with asthma, we performed an additional analysis

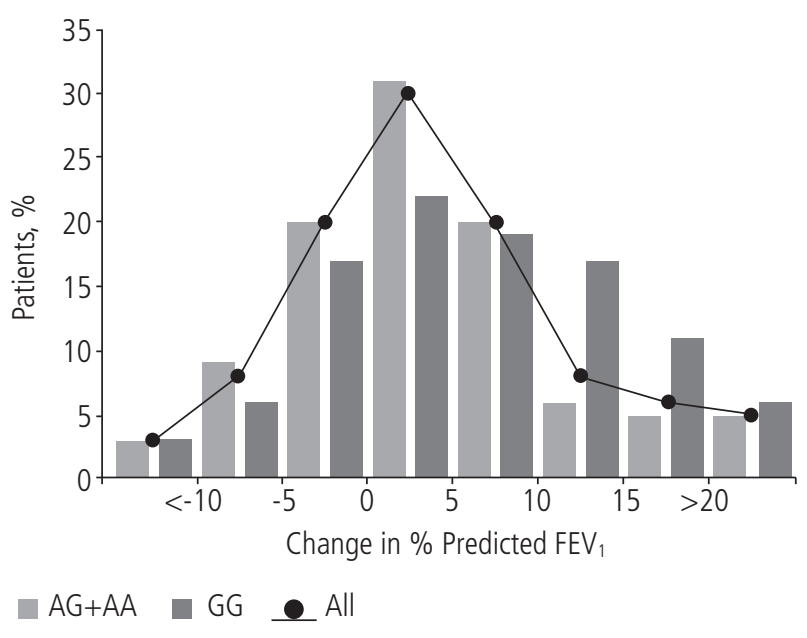

Figure 1. Change in $\mathrm{FEV}_{1} \%$ predicted after at least 3 years of treatment in patients not stratified to genotype and in patients stratified according to the rs37973 in GLCCI1 genotype. A clear shift towards a better response can be seen in GG patients. 
where patients were stratified according to smoking and atopic status. After 3 months of ICS treatment, the change in $\mathrm{FEV}_{1}$, $\%$ predicted was higher in patients with the GG genotype than in patients with the AG+AA genotype $(7.5 \%$ vs $4 \%, P=.049)$. When patients were divided according to smoking status, this association was confirmed only in nonsmokers ( $8 \%$ vs $4 \%$, $P=.038$ ). There were no genotype-dependent changes in $\mathrm{FEV}_{1}$, $\%$ predicted when patients were stratified according to atopy (Table 2, Figure 2).

\section{Long-term Treatment and GLCCI1}

To assess whether there was a difference in the pharmacogenetics of rs37973 in GLCCI1 after short- or longterm treatment (at least 3 years), we also analyzed changes in $\mathrm{FEV}_{1}, \%$ predicted and treatment response (good vs poor) after at least 3 years of treatment. As with the short-term response, patients with atopy and smokers were analyzed as separate subgroups in the analysis of long-term response. After at least 3 years of treatment, genotype specific differences in treatment outcome were even more evident than after 3 months (Figure 2). Patients with the GG genotype experienced a 7\% improvement in $\mathrm{FEV}_{1}, \%$ predicted compared with $3.5 \%$ in $\mathrm{AG}+\mathrm{AA}(P=.041)$ (Figure 2$)$, and similar genotype-dependent changes were found only in nonsmokers ( $7 \%$ vs $3 \%, P=.035)$. Even though no difference in the success of treatment (good vs poor response) was observed when the entire group of patients was analyzed, genotype-specific treatment success was highly evident in nonsmokers. We observed that $21 \%$ of nonsmokers with a good response had the GG genotype and that only $4 \%$ of patients had a poor response $(\mathrm{OR}, 6.95 ; 95 \% \mathrm{CI}$, $0.90-53.58 ; P=.030)$. In contrast, $49 \%$ of smokers with a good response had the AA genotype, whereas none $(0 \%)$ of the patients with a poor response had the AA genotype (OR, 16.28; $95 \%$ CI, $0.89-299.10 ; P=.015)$. There were no differences in response to treatment between smokers and nonsmokers when they were not stratified according to genotype. Furthermore, atopic patients with the GG genotype had a $12 \%$ increase in $\mathrm{FEV}_{1}, \%$ predicted compared with $3 \%$ in patients with the AG+AA genotype $(P<.001)$, and all atopic patients with the GG genotype had a good response to treatment compared with $75 \%$ of the $\mathrm{AG}+\mathrm{AA}$ patients (OR, 9.84; $95 \% \mathrm{CI}, 0.56-172.80$; $P=.035)$, whereas there was no genotype-specific difference in nonatopic patients (Table 2).

\section{ICS Only or ICS+LABA and GLCCI1}

In order to test the modifying effect of LABAs on the pharmacogenetics of ICSs, patients were further divided into 2 groups. In the first group, patients were treated only with ICSs $(\mathrm{n}=121)$, and in the second, patients received a combination of ICSs and LABAs $(n=87)$. We found an association between genotype and change in $\mathrm{FEV}_{1}, \%$ predicted after at least 3 years of treatment only in patients receiving ICSs alone; patients with GG had an $8.5 \%$ increase compared with a $3 \%$ increase in the AG+AA group $(P=.001)$, and all patients with the GG genotype had a good response to treatment, compared with $72 \%$ of the $\mathrm{AG}+\mathrm{AA}$ patients (OR, 15.90; 95\% CI, 0.93-271.90; $P=.007)$. On the other hand, there was no genotype-associated response in patients who received ICS+LABA.

Table 2. Association of GLCCI1 Polymorphism rs37973 With Change of FEV $1 \%$ Predicted After 3 Months and $>3$ Years of Treatment and Patients Response

\begin{tabular}{|c|c|c|c|c|c|c|c|}
\hline $\begin{array}{l}\text { rs37973 } \\
\text { GLCCI1 }\end{array}$ & Genotype & $\begin{array}{l}\text { Change in } \\
\text { FEV }_{1} \% \\
\text { Predicted } \\
\text { After } 3 \text { mo }\end{array}$ & $P$ Value & $\begin{array}{l}\text { Change of } \\
\text { FEV }_{1} \% \\
\text { Predicted } \\
\text { After }>3 \text { y }\end{array}$ & $P$ Value & $\begin{array}{c}\text { Patients } \\
\text { With Good } \\
\text { Response } \\
(\%)\end{array}$ & $\begin{array}{l}P \text { Value } \\
\text { OR } \\
95 \% \mathrm{CI}\end{array}$ \\
\hline All patients & $\begin{array}{c}\mathrm{GG} \\
\mathrm{AG}+\mathrm{AA}\end{array}$ & $\begin{array}{l}7.5 \\
4.0\end{array}$ & .050 & $\begin{array}{l}7.0 \\
3.5\end{array}$ & .041 & $\begin{array}{l}92 \\
81\end{array}$ & $>.99$ \\
\hline Smokers & $\begin{array}{c}\mathrm{GG} \\
\mathrm{AG}+\mathrm{AA}\end{array}$ & $\begin{array}{l}6.0 \\
5.0\end{array}$ & $>.99$ & $\begin{array}{l}7.0 \\
4.0\end{array}$ & $>.99$ & $\begin{array}{l}78 \\
86\end{array}$ & $>.99$ \\
\hline Nonsmokers & $\begin{array}{c}\mathrm{GG} \\
\mathrm{AG}+\mathrm{AA}\end{array}$ & $\begin{array}{l}8.0 \\
4.0\end{array}$ & .038 & $\begin{array}{l}7.0 \\
3.0\end{array}$ & .035 & $\begin{array}{l}96 \\
79\end{array}$ & $\begin{array}{c}.030,6.95 \\
0.90-53.58^{\mathrm{a}}\end{array}$ \\
\hline Atopic patients & $\begin{array}{c}\mathrm{GG} \\
\mathrm{AG}+\mathrm{AA}\end{array}$ & $\begin{array}{l}7.0 \\
4.0\end{array}$ & $>.99$ & $\begin{array}{c}12.0 \\
3.0\end{array}$ & $<.001$ & $\begin{array}{c}100 \\
75\end{array}$ & $\begin{array}{c}.035,9.86, \\
0.56-172.80^{\mathrm{b}}\end{array}$ \\
\hline Nonatopic patients & $\begin{array}{c}\mathrm{GG} \\
\mathrm{AG}+\mathrm{AA}\end{array}$ & $\begin{array}{l}7.5 \\
4.0 \\
\end{array}$ & $>.99$ & $\begin{array}{l}4.5 \\
3.0\end{array}$ & $>.99$ & $\begin{array}{l}86 \\
85\end{array}$ & $>.99$ \\
\hline ICS only & $\begin{array}{c}\mathrm{GG} \\
\mathrm{AG}+\mathrm{AA}\end{array}$ & $\begin{array}{l}6.0 \\
4.0\end{array}$ & $>.99$ & $\begin{array}{l}8.5 \\
3.0\end{array}$ & .001 & $\begin{array}{c}100 \\
72\end{array}$ & $\begin{array}{c}.007,15.90 \\
0.93-271.90^{\mathrm{c}}\end{array}$ \\
\hline ICS+LABA & $\begin{array}{c}\mathrm{GG} \\
\mathrm{AG}+\mathrm{AA}\end{array}$ & $\begin{array}{l}4.5 \\
5.0\end{array}$ & $>.99$ & $\begin{array}{l}8.5 \\
5.0\end{array}$ & $>.99$ & $\begin{array}{l}81 \\
93\end{array}$ & $>.99$ \\
\hline
\end{tabular}

Abbreviations: ICS, inhaled corticosteroids; LABA, long-acting ß-agonists.

aStatistical power for detection of the association was $92 \%$.

bstatistical power for detection of the association was $56 \%$.

cStatistical power for detection of the association was $87 \%$. 

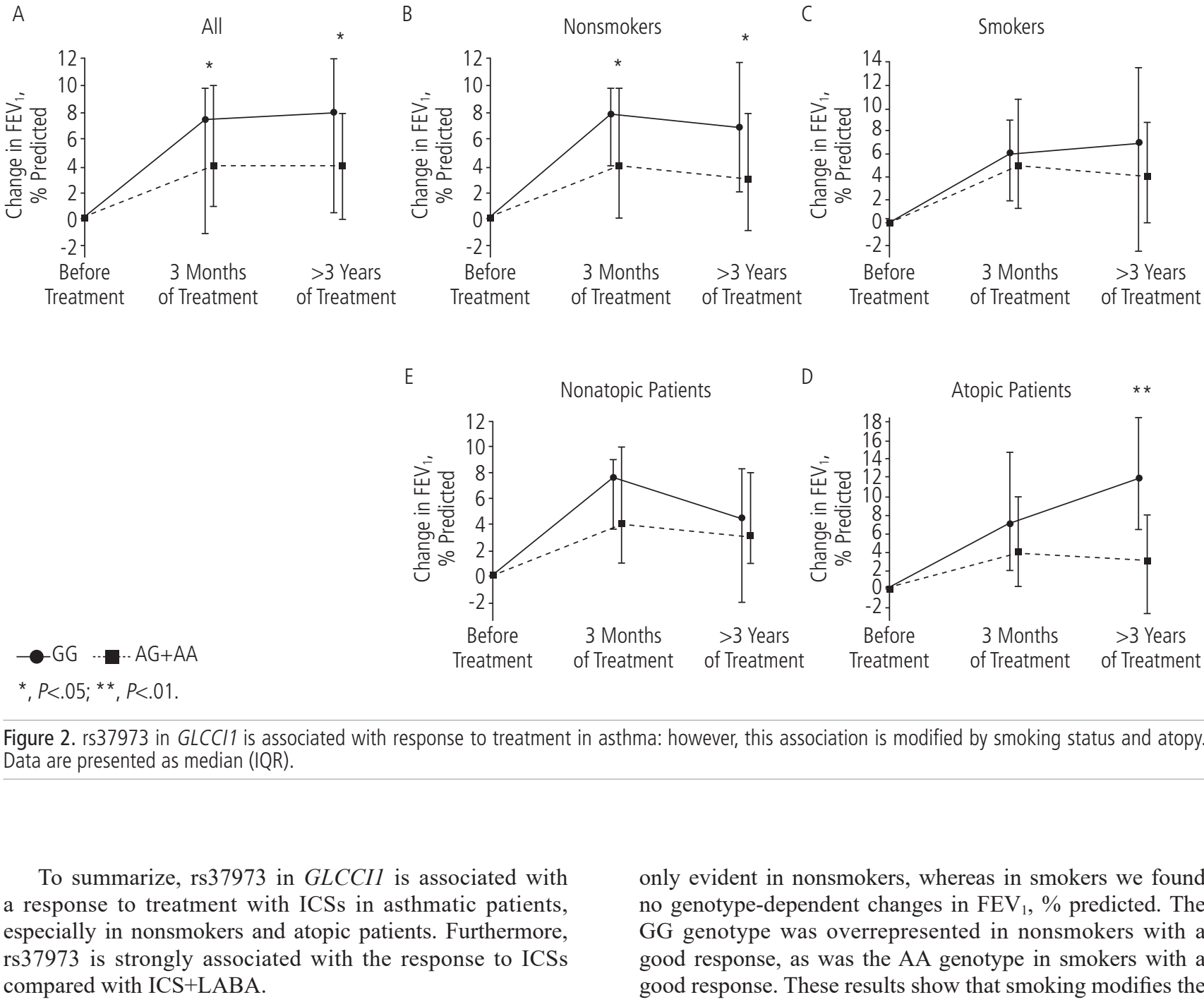

\section{Discussion}

ICSs are one of the most commonly used drugs for treatment of asthma. Despite their effectiveness, response to treatment is highly variable, is likely to be multifactorial, and depends considerably on the patient's genetic background [18]. Numerous genes are associated with the response to asthma treatment [19]. However, the first GWAS to analyze the pharmacogenomics of asthma revealed that the GLCCI1 gene, located on $17 \mathrm{p} 21.3$, was the major candidate associated with response to ICSs. The AA genotype in polymorphism rs37973, which is located in the promoter region of GLCCI1, was associated with a more marked improvement in lung function [10].

We performed a study on 208 well-characterized adult asthma patients treated with ICSs and analyzed whether there was an association between response to treatment and the GLCCI1 polymorphism rs37973. We found genotypedependent differences in response. The change in $\mathrm{FEV}_{1}, \%$ predicted was higher in patients with the GG genotype when a recessive genetic model was used. This association was

only evident in nonsmokers, whereas in smokers we found no genotype-dependent changes in $\mathrm{FEV}_{1}, \%$ predicted. The GG genotype was overrepresented in nonsmokers with a good response, as was the AA genotype in smokers with a good response. These results show that smoking modifies the association between rs37973 in GLCCI1 and the response to ICSs in asthma patients. Further analysis showed that the GG genotype is associated with a greater improvement in lung function only in atopic patients and that an association in the same direction was evident only in patients receiving ICSs alone. The causes of variations in drug response are numerous and complex [20]. The data on smoking and atopic status included in our analysis revealed the importance of environmental and phenotype-related variables on the pharmacogenetic effect of the polymorphism analyzed. However, despite an association between rs37973 and response to treatment, our results are contrary to the association found in the GWAS by Tantisira et al [10], who reported a 3-fold better response in patients with the AA genotype [10]. Because of the conflicting results, further studies are needed.

The GLCCI1 gene is highly expressed in the lymph nodes, leukocytes, breast tissue, testes, adrenal glands, lungs, kidneys, and at other sites [21]. Because of its high glomerular expression [22], GLCCI1 rs37973 was also analyzed in patients with nephrotic syndrome receiving oral corticosteroids, although no pharmacogenetic association was found [23]. Variants in GLCCI1 in lymphoblastoid B cells were shown to be associated 
with decreased expression of GLCCI1, both at baseline and in response to dexamethasone [10]. We used a bioinformatics tool to highlight the mechanism by which rs37973 could modify gene expression. rs37973 and other GLCCI1 polymorphisms in strong linkage disequilibrium ( $\mathrm{r} \geq .99$ ), namely, rs37969, rs37971, and rs37972, are located in enhancer histone marks, at DNAse and protein binding sites, and in regulatory motifs [24]. The methyltransferases H3K4Me1 and H3K4Me3 are located directly in rs37973 [25]. These data suggest that there could be a functional explanation for the association between rs37973 and response to asthma treatment. It could be hypothesized that altered methylation because of this SNP results in changed gene expression. Methylation has an important role in the action of corticosteroids, as its effectiveness is reduced by methyltransferase inhibitors [26].

The pharmacogenetic variants in asthma analyzed to date account for only a small part of genetic variability in the response to asthma treatment; therefore, further studies are needed to resolve the environmental effect and the possible role of genetic interactions that are particularly important when each feature involved only demonstrates a minor effect [27]. Ours is the first study to analyze how environment and atopy influence the pharmacogenetics of GLCCII in asthma patients. Our results show the importance of disease phenotype and analysis in pharmacogenetics, especially in a heterogeneous disease such as asthma.

In conclusion, rs37973 in GLCCI1 is associated with response to treatment in asthma; however, this association is considerably modified by smoking status and atopy. Because our results are in contrast with those found in GWAS [10], further studies are necessary to elucidate the role of rs 37973 in the pharmacogenetics of ICSs in asthma patients.

\section{Acknowledgments}

We are grateful to all the patients who participated in this study and to J Šelb for his skilful assistance in performing the statistical power calculations using $\mathrm{R}$.

\section{Funding}

This research was supported by grant no. P3-0360 from the Slovenian Research Agency.

\section{Conflicts of Interest}

The authors declare that they have no conflicts of interest.

\section{References}

1. Global Initiative for Asthma. Global Strategy for Asthma Management and Prevention NIH Pub. Updated 2017. [Accessed June 15th, 2017]. Available from: www.ginasthma.org

2. Barnes PJ, Adcock IM. How do corticosteroids work in asthma? Ann Intern Med. 2003;13:359-70.

3. Mauad T, Bel EH, Sterk PJ. Asthma therapy and airway remodeling. J Allergy Clin Immunol. 2007;120:997-1009.

4. Spears M, Thomson N. Factors Influencing Individual Variability in the Therapeutic Response to Corticosteroids in Asthma. Curr Respir Med Rev. 2006;2:197-209.
5. Campo P, Rodríguez F, Sánchez-García S, Barranco P, Quirce $S$, Pérez-Francés $C$ et al. Phenotypes and endotypes of uncontrolled severe asthma: new treatments. J Investig Allergol Clin Immunol. 2013;23:76-88.

6. Wadsworth SJ, Sandford AJ. Personalised medicine and asthma diagnostics/management. Curr Allergy Asthma Rep. 2013;1:118-29.

7. Lopert $A$, Rijavec $M$, Žavbi $M$, Korošec $P$, Fležar $M$. Asthma treatment outcome in adults is associated with rs9910408 in TBX21 gene. Sci Rep. 2013;3:2915.

8. Balantic M, Rijavec M, Skerbinjek Kavalar M, Suskovic S, Silar $M$, Kosnik $M$ et al. Asthma treatment outcome in children is associated with vascular endothelial growth factor A (VEGFA) polymorphisms. Mol Diagn Ther. 2012;16:173-80.

9. Tantisira KG, Lake S, Silverman ES, Palmer LJ, Lazarus $R$, Silverman EK. Corticosteroid Pharmacogenetics: Association of sequence variants in CRHR1 with improved lung function in asthmatics treated with inhaled corticosteroids. Hum Mol Genet. 2004;13:1353-9.

10. Tantisira KG, Lasky-Su J, Harada M, Murphy A, Litonjua AA, Himes BE et al. Genomewide association between GLCCI1 and response to glucocorticoid therapy in asthma. N Engl J Med. 2011;365:1173-83.

11. McGeachie MJ, Wu AC, Chang HH, Lima JJ, Peters SP, Tantisira KG. Predicting inhaled corticosteroid response in asthma with two associated SNPs. Pharmacogenomics J. 2013;13:306-11.

12. Hosking L, Bleecker E, Ghosh S, Yeo A, Jacques L, Mosteller M. GLCCI1 rs37973 does not influence treatment response to inhaled corticosteroids in white subjects with asthma. J Allergy Clin Immunol. 2014;133:587-9.

13. Portelli M, Sayers I. Genetic basis for personalized medicine in asthma. Expert Rev Respir Med. 2012;2:223-36.

14. Litonjua AA, Silverman EK, Tantisira KG, Sparrow D, Sylvia JS, Weiss ST. Beta 2-adrenergic receptor polymorphisms and haplotypes are associated with airways hyperresponsiveness among nonsmoking men. Chest. 2004;126:66-74.

15. Telleria JJ, Blanco-Quiros A, Varillas D, Armentia A, FernandezCarvajal I, Jesus Alonso $M$ et al. ALOX5 promoter genotype and response to montelukast in moderate persistent asthma. Respir Med. 2008;102:857-61.

16. Lötvall J, Akdis CA, Bacharier LB, Bjermer L, Casale TB, Custovic A et al. Asthma endotypes: a new approach to classification of disease entities within the asthma syndrome. J Allergy Clin Immunol. 2011;127:355-60.

17. $R$ Core Team. R: A language and environment for statistical computing. R Foundation for Statistical Computing, Vienna, Austria. 2013. Available from: http://www.R-project.org/.

18. Szalai C, Ungvári I, Pelyhe L, Tölgyesi G, Falus A. Asthma from a pharmacogenomic point of view. Br J Pharmacol. 2008;153:1602-14.

19. Tse SM, Tantisira K, Weiss ST. The pharmacogenetics and pharmacogenomics of asthma therapy. Pharmacogenomics $J$. 2011;11:383-92.

20. Ma Q, Lu AY. Pharmacogenetics, pharmacogenomics, and individualized medicine. Pharmacol Rev. 2011;63:437-59.

21. Petryszak R, Burdett T, Fiorelli B, Fonseca NA, Gonzalez-Porta $M$, Hastings $E$ et al. Expression Atlas update - a database of gene and transcript expression from microarray and 
sequencing-based functional genomics experiments. Nucleic Acids Res. 2014;42 (Database issue):D926-32.

22. Takemoto M, He L, Norlin J, Patrakka J, Xiao Z, Petrova $T$ et al. Large-scale identification of genes implicated in kidney glomerulus development and function. EMBO J. 2006;25:1160-74.

23. Cheong HI, Kang HG, Schlondorff J. GLCCI1 single nucleotide polymorphisms in pediatric nephrotic syndrome. Pediatr Nephrol. 2012;27:1595-9.

24. Ward LD, Kellis M. HaploReg: a resource for exploring chromatin states, conservation, and regulatory motif alternations within sets of genetically linked variants. Nucleic Acids Res. 2011;40 (Database issue):D930-4.

25. Encode Project Consortium: The ENCODE (ENCyclopedia of DNA Elements). Science. 2004;306:636-40.

26. Kagoshima M, Wilcke T, Ito K, Tsaprouni L, Tsaprouni L, Barnes PJ et al. Glucocorticoid-mediated transrepression is regulated by histone acetylation and DNA methylation. Eur J Pharmacol. 2001:429:327-34.

27. Lane $H Y$, Tsai GE, Lin E. Assessing gene-gene interactions in pharmacogenomics. Mol Diagn Ther. 2012;16:15-27.
- Manuscript received August 9, 2017; accepted for publication January 9, 2018.

\section{- Matija Rijavec}

Laboratory for Clinical Immunology and Molecular Genetics

University Clinic of Respiratory and Allergic Diseases

Golnik

Golnik 36

4204 Slovenia

E-mail: matija.rijavec@klinika-golnik.si 